\title{
The Study of Character-Assessment Book Use in Junior High School
}

\author{
Eva Meizara Puspita Dewi, Harlina Hamid, Novita Maulidya Djalal \\ Faculty of Psychology Universitas Negeri Makassar \\ St. Mappala No. 1, Gunung Sari, Makassar, South Celebes, Indonesia \\ Email: evabasti@yahoo.com
}

\begin{abstract}
Character education is a deliberate effort to develop good character based on existing policies. In adolescence i.e. junior high, individuals have a character base so that the school and parent's task is to strengthen the character. The purpose of this study is to examine the effectiveness of assessment books that are filled by parents in strengthening the positive character of students. This research uses qualitative design because it wants to explore a material that is the use of behaviour control book so that it will be a lot of survey data and description from the start of its manufacture until the evaluation of its effectiveness. Subjects in this study i.e. parents, principals and teachers, as well as students of Junior High School UNISMUH as the core subject. Data collection method in this research is questionnaire, observation and focus grouping discus (FGD). Analysis of data used is descriptive quantitative analysis in the form of percentage of the questionnaire filled by parents. Furthermore, qualitative data analysis to describe FGD results in the form of field notes. The results of this study are (1) characters that require reinforcement include discipline behaviour, confidence, courage, and independence, and (2) character appraisal books filled by parents considered less effective in reinforcing the positive character of students due to the lack of parental involvement and less according to the stage of adolescent development.
\end{abstract}

Keywords:Character-Assessment, Book Use, Junior High School.

\section{PRELIMINARY}

Character education is a deliberate effort to develop good character based on core policies that are objectively good for individuals and society. Various parties voiced the importance of education in school cadres. Character education is regarded as one of the important ways to overcome the moral damages of the already-at-worrisome society, especially in relation to the spread of deviant behaviour such as: cruel, violent acts, indifference to courtesy, drugs, pornography to free sex (Saptono, 2010 ).

This is in line with Hidayatullah (2010) which states that some of the factors that cause low character education are: firstly, education system that less emphasize character formation but more emphasize intellectual development, for example education evaluation system emphasize cognitive / academic aspect, like National Exam. Secondly, environmental conditions are less supportive of good character building. School is not a place where the whole nation's problems can be solved. But schools promise a lot about improving a nation in the future. The function of personal formation, especially the development of intellectual virtue, as well as its impact on social life is what makes character education urgent to be developed as an alternative strategy of quality improvement. School has a big role in shaping the character of the nation. (Koesuma, D. 2010).

The family is the smallest unit in society that has an important role in developing individual character and personality. The values of life first recognized by the child come primarily from their interaction with parents. How parents communicate with him, express his affection, anger and include interacting with others. That is, patterns of behaviour and habits that are applied in the family will be used as a reference of children in behaving and behaving. This is where the initial formation of behaviour habituation or called by character.

The formation of effective characters is to provide a consistent or relatively similar environment between home and school. Schools that are aware of or concerned with the development of the character of the students are not many because it takes additional energy in focus to design and monitor the character of students. Junior High School UNISMUH Makassar is one of the schools that care about character education so want cooperation with parents to work hard to strengthen positive character in child. However, this process is not easy, it is necessary to have a mutual agreement between the school and the parents which aspects of the character will be strengthened so that the process will be clear and measurable.

The planting of characters actually begins at the age of childhood ie early childhood and kindergarten and elementary. In adolescence the first middle-age children have a character base so that the school and parent's task is to strengthen the character. Researchers and principals discuss about this and look for a breakthrough or how to reinforce a student's positive character. The result of this discussion summarizes the need for the preparation of a student character assessment book. Thus, researchers will conduct exploratory studies in the preparation of character assessment books and simultaneously test their effectiveness in the formation of character of students of Junior High School UNISMUH Makassar.

The problems to be answered in this research are: The problems raised in this study are:

1. What aspects will be developed in character education at UNISMUH Junior High School?

2. Is the character assessment book effective in reinforcing the positive character of the student?

\section{Character Definition}

Saptonno (2011) which states the term character comes from the Greek word Karasso which means the basic 'blueprint' or fingerprint format. Another opinion states that the term character comes from the Greek language Charassein which means making in or making sharp. Conceptually the term character is understood in a sense. First, it is deterministic which means a collection of spiritual conditions that have been bestowed. The fixed nature of a person is unchangeable and a special sign that distinguishes it from others. Second, is nondeterministic or dynamic that is the level of strength or toughness of a person in overcoming the spiritual conditions that have been given.

Herman Kertajaya (2010) suggests that the character is a "characteristic" possessed by an object or individual. This 
characteristic is "authentic" and is rooted in the individual's personality and is the engine of how one acts, behaves, says and responds to something. This characteristic reminds others about the person and determines the likes or dislikes of the environment for the individual. Characters provide consistency, integrity and energy.

The above explanation makes the researcher more appropriate to choose using the term strengthening the character instead of the character formation. This is because students actually have a basic character from early childhood and elementary school. It is now entering junior high school whose age is entering in the adolescent phase so it has entered in the process of strengthening it.

The basic question is whether the character can be changed, Munir (2010) explained that looking at the definition alone, already has the meaning that the character is difficult to change. If something is easy to change, it is not a character. Maybe it's just the nature, attitude, views of opinion or attention. Therefore, character formation is done early and change it after the character is formed is a work that is not light. It takes long therapy, consistency, cost, time, thought and enormous energy.

Sulhan (2010) states there are 4 steps in the formation of characters, namely:

a. Incorporating the concept of character in every learning activity, instilling the good value to the child (knowing the good);

b. Create a slogan that is able to grow good habits in all the behaviour of the school community;

c. Continuous monitoring is a manifestation of character building implementation; and

d. Assessment of parents, this is because the synergy between school and family is expected in the formation of character.

\section{METHOD OF APPLYING CHARACTER EDUCATION}

Hidayatullah (2010) explains about strategies in character education can be made through exemplary, disciplinary planting, habituation, creating a conducive atmosphere, integrity and internalization in creating a conducive atmosphere such as the existence of cooperation with parents. Since the child is enrolled to enter the school, parents are informed of the matters of his / her responsibility. It should be emphasized again that the school should be able to condition the parents to provide guidance or counseling to various activities of children both preventive and curative. For example, schools that require students to pray, then parents also control the implementation of prayers at home, better if parents can provide examples at home. On the other hand, the problems faced by students must be known to the school and parents so that the problem becomes a common problem. Parents should be involved in solving their child's problems.

Kaufman (Saptono, 2010) states there are 11 principles of character education, including:

a. Schools must commit to core ethical values;

b. Characters must be understood in their entirety, including knowledge or thoughts, feelings and actions;

c. Schools should be proactive and act systematically in character learning and not just wait for opportunities to arrive;

d. Schools must build an atmosphere of mutual care for each other and become a small world of a caring society;

e. The opportunity to practice moral action must be varied and available to all.

f. Academic studies should be the main thing; g. Schools need to develop ways to increase students' intrinsic motivation that includes core values;

h. Schools need to work together and dialogue norms about character education

i. Teachers and students must share in the moral leadership of the school;

j. Parents and communities should be colleagues in character education at school;

k. Evaluation of the effectiveness of character education in schools, especially of teachers and employees and students should be evaluated.

Scaffer (Saptono 2010) emphasizes the importance of the role of family / parents involved in character formation. This is because the family is the main character educator so it has the most important influence. The task of the school is to reinforce the values of the positive character taught at home. Schools as much as possible to provide parenting guidance related to character education programs in school. Involve parents in planning character education programs in school and give family homework to do in order to increase the agreed character. Also make regular reports to parents as a result of the evaluation. The most important thing is the establishment of positive communication between parents and school. Sulhan (2010) insists to be a character-based school with not enough vision, mission and goals. More concretely there is a foundation: commitment, motivation and togetherness.

\section{RESEARCH METHOD}

This research uses qualitative design because it wants to explore a material that is the use of behaviour control book so that it will be a lot of survey data and description from the start of its manufacture until the evaluation of its effectiveness. According to Kline (DarminSudarman 2000) Research evaluation is intended to measure the outcome of a particular program, product or activity. This evaluation research framework is simple and horizontal, and does not focus on the inter-variables.

The term limits used in this study are as follows: Character assessment books are: Books deliberately designed by researchers and the school in monitoring some aspects that want to be developed by the school and parents. This assessment book will be distributed to parents to be filled in by observing the behaviour of the child during the home. As for the aspect of the effectiveness in question is a change in the character of the mean of students after the treatment of behaviour monitoring is through the character assessment book.

The Procedures of carrying out research have been done in preparation, implementation until evaluation of the use of character assessment books, namely:

a. Make a survey questionnaire that will be shared with parents about what aspects of character they want to strengthen for their children so that the school emphasizes the same.

b. The results of the survey will make the workshop materials with the teachers to formulate the assessment form.

c. The character assessment book will be validated by: principal, psychologist and parents.

d. Socialization of filling in book character assessment of students during home and will be distributed to parents to be filled for a month by ticking every day.

e. The book is returned to school for the results and tabulated so that a quantitative graph of change and evaluation will be obtained. 
f. FGDs on parents and teachers on the execution and effects of qualitative character assessment books are input inputs from parents.

In this research that will be subjected to several segments, namely: Parents are involved in the determination of character aspects to be measured and in the filling of character assessment books. School heads and teachers to participate formulate and provide input on the making of character assessment and monitoring of the course character assessment through a control book that must be reassembled into the school. Students of UNISMUH Junior High School are the core subjects that are observed and characterized.

Data collection methods used in this study are: parent survey questionnaire to determine the character aspect to be assessed, observation of student behaviour that will be recorded through the character book that has been created and focus grouping discus (FGD) to know the parent's response to the character assessment book, evaluation of character assessment books, and behaviours that arise from the 1 monthbehaviour assessment process.

Furthermore, the data will be analysed by using two ways namely: descriptive quantitative analysis in the form of percentage of questionnaires filled by parents and the tabulation of character assessment books. Furthermore, qualitative data analysis to describe FGD results in the form of field notes. This qualitative data analysis uses Miles and Hubberman (Emzir 2012) models, and through three stages of data reduction, data presentation and conclusion.

\section{RESULT AND ANALYSIS}

\section{Result of survey of Questionnaire}

The questionnaire results were distributed to the parents of students, the following results were obtained:

Table 1. Results of progressive progress progression of learners since school at Lab. School of Junior High School Unismuh Makassar 2016/2017

\begin{tabular}{|c|l|r|}
\hline No & Progres Siswa & Persentase (\%) \\
\hline 1 & Submissive & $52 \%$ \\
\hline 2 & Diligent & $52 \%$ \\
\hline 3 & Prayer & $42 \%$ \\
\hline 4 & Understanding & $21 \%$ \\
\hline 5 & Good morals & $13 \%$ \\
\hline 6 & Learning is on the rise & $12 \%$ \\
\hline 7 & Care & $11 \%$ \\
\hline 8 & Good intercourse & $11 \%$ \\
\hline 9 & To be responsible & $7 \%$ \\
\hline 10 & Memorization & $7 \%$ \\
\hline 11 & Independent & $7 \%$ \\
\hline 12 & Courageous & $6 \%$ \\
\hline 13 & Confidence & $6 \%$ \\
\hline 14 & Polite & $6 \%$ \\
\hline 15 & Be well behaved & $6 \%$ \\
\hline 16 & Discipline & $2 \%$ \\
\hline 17 & Religious Knowledge & $7 \%$ \\
\hline
\end{tabular}

Table 2, Results Aspects of character possessed by learners

\begin{tabular}{|c|l|r|}
\hline No & $\begin{array}{c}\text { Aspects of character possessed by } \\
\text { learners }\end{array}$ & Percentage (\%) \\
\hline 1 & Hafidz & $10 \%$ \\
\hline 2 & Concern & $10 \%$ \\
\hline 3 & Sholeh / sholeha & $8 \%$ \\
\hline 4 & Morals & $8 \%$ \\
\hline 5 & Respecting others (polite) & $8 \%$ \\
\hline 6 & Independent & $7 \%$ \\
\hline 7 & Diligent & $6 \%$ \\
\hline 8 & My good behaviour & $5 \%$ \\
\hline 9 & Communicate well & $5 \%$ \\
\hline 10 & Integrity & $4 \%$ \\
\hline
\end{tabular}

\begin{tabular}{|l|l|c|}
\hline 11 & To be responsible & $4 \%$ \\
\hline 12 & Patient & $4 \%$ \\
\hline 13 & Honest & $4 \%$ \\
\hline 14 & Consistent & $4 \%$ \\
\hline 15 & Reading Quran well & $3 \%$ \\
\hline 16 & Confidence & $2 \%$ \\
\hline 17 & Good decision maker & $2 \%$ \\
\hline 18 & Discipline & $1 \%$ \\
\hline
\end{tabular}

Table 3, Results unexpected characters exist in the student

\begin{tabular}{|c|l|r|}
\hline No & Unexpected Characters & Percentage (\%) \\
\hline 1 & Naughty & $12 \%$ \\
\hline 2 & Idlers & $11 \%$ \\
\hline 3 & Spoiled & $10 \%$ \\
\hline 4 & Dissident & $9 \%$ \\
\hline 5 & Excessive HP Main & $9 \%$ \\
\hline 6 & Reckless & $9 \%$ \\
\hline 7 & Impolite & $8 \%$ \\
\hline 8 & Undisciplined & $7 \%$ \\
\hline 9 & Not responsible & $6 \%$ \\
\hline 10 & Negative characters & $6 \%$ \\
\hline 11 & Selfish & $4 \%$ \\
\hline 12 & No religious knowledge & $4 \%$ \\
\hline 13 & saying no good & $4 \%$ \\
\hline 14 & Wasteful & $3 \%$ \\
\hline 15 & Temperaments & $2 \%$ \\
\hline 16 & Dishonest & $2 \%$ \\
\hline 17 & Arrogant & $1 \%$ \\
\hline
\end{tabular}

Based on the parent-dispersed survey, the results obtained that the character that developed during the students attended junior high school UNISMUH is the character of obedient, as well as characters related to worship activities such as praying and reciting, although religious knowledge is still less than optimal. Meanwhile, the less developed characters in the students during the junior high school UNISMUH is a character related to disciplinary behaviour, courtesy, confidence, courage, independence, communicate and behave well. The results are in line with parents' expectations of unwanted characters in students that are naughty, spoiled, dissident, and lazy characters.

Thus, it can be concluded that the character that has been developed in the student character related to the behaviour of obedient and worship activities. Furthermore, the characters that still need to be strengthened in order to develop well include student-related behaviours (discipline, self-confidence, courage, and self-reliance) and behaviour related to others (good manners, communicating and behaving well).

2. FGD results with parents about this character assessment book, shows there are 2 groups of opinions, namely: there is a positive feeling that helped with this to the next page

The effectiveness of the character assessment book was obtained based on the FGD, which is part of the interview method conducted in groups, namely collecting a number of parents. The number of parents who are willing to participate in the activities of 50 people who are divided into discussion groups. The focus group discussed topics on the research agenda of parents' responses to the character assessment book.

The results obtained from the data retrieval i.e. there are two responses on the character assessment book:

a.) There is a parent who states that the character penalty book is effective because it is enough to help the parents in controlling their child. In addition, parents also include their children to be involved in filling the book so that communication occurs between children and parents. 
b.) There is a parent who states that character appraisal books are ineffective because parents assume the child has behaved well due to sincerity to worship Allah Almighty, not because of punishment or gifts alone. Parents assume that character valuation books are no longer suitable for children who have entered adolescence, because adolescents behave due to rational reasons, no longer due to punishment / gifts alone. The character assessment book is considered to be more appropriate for children in primary school.

c.) There is a parent who states that character appraisal books are very ineffective because parents who want their children to be rated positive by teachers in schools tend to want to show good behaviour to their children, so as not to give information or data about actual teenage behaviour when at home. The information given by parents is hope, not fact.

d.) Some parents have not used this assessment book because they do not have spare time, heavy work activities, and assume that the implementation of the valuation book is complicated and less effective when it is given to adolescents.

\section{DISCUSSION}

Kertajaya (2010) suggests that character is a "characteristic" possessed by an object or individual. This characteristic is "authentic" and is rooted in the individual's personality and is the engine of how one acts, behaves, says and responds to something.

Activity to measure the attainment of characters formed based on learning outcomes is called character assessment. Andersen (1980) states that one method that can be used to measure one's character is the method of observation. The use of observational methods is based on the assumption that affective characteristics can be seen from the behaviours or displayed deeds, psychological reactions, or both.

Observation of the characteristics of learners is done at the place of the occurrence of learning and teaching activities as well as in the school environment. To find out the state of the learner, the educator must prepare to record every action that arises from the learner related to the affective learner indicator of the learner. Therefore, it is necessary to determine the indicator of the substance to be measured. Such as honest indicators, responsibility, cooperation, respect for others, want to always do good, and so on.

Based on the results of the survey through questionnaires, it is obtained the data about student character observation displayed in school and at home. Students' characteristics are observed through behaviours that are very rarely displayed by students at home or school i.e. discipline, self-confidence, good al Quran reading, integrity, responsible, patient, honest, consistent, and good behaviour and communicate well only as big as that. It is in line with Saptono's (2010) opinion that the deviant behaviour that often occurs among teenagers such as: cruel, violent acts, indifference to courtesy, drugs, pornography to free sex (Saptono, 2010).

Kolhberg (Colby \& Kohlberg, 1987) states that human beings basically have the ability to evaluate whether a behaviour is good or bad value called moral reasoning or moral reasoning (Colby \& Kohlberg, 1987). By having a reasoning morale someone will have a strong thinking base for making a decision to behave good or bad. Thus, Kohlberg (Colby \& Kohlberg, 1987) asserts that moral reasoning can be called a predictor of behaviour. It shows that the character of the student is reflected in the undisciplined, unconfident behaviour, does not read the good Quran, integrity, irresponsibility, impatience, dishonesty, inconsistency, and bad behaviour and communicate well is the result of an evaluation done by the students on the behaviour that he wants to emerge. This is in line with the results of Malti's research, Gasser \&Buchmann (2009) which shows the result that individuals who have aggressive behaviour tend to provide moral reasoning oriented to punishment or sanctions. If it refers to the moral concept of reasoning, it can be concluded that adolescents with behaviour that tend to deviate from morals have a low moral reasoning (at the punishment and obidience orientation stage) compared to children who exhibit moral behaviour.

Based on the data obtained, parents argue that the use of character assessment books is not effective enough to strengthen the moral character of adolescents because of the adolescent's view that their behaviour is right because they have a reason that they think is true. Whereas Kohlberg (Colby \& Kohlberg, 1987) states that the high moral stages of a person can be formed and strong due to a person's evaluation of his or her behaviour whether good or bad is determined by social contracts, common rights, and measures that have been tested and agreed upon by together. Therefore, the support of the social environment to create rules or measures for good student behaviour is necessary.

In essence, reasoning morality is something that can be shaped and developed through the exchange of views with people in the neighbourhood (Colby \& Kohlberg, 1987). The sooner the child is taught to understand the moral logic, the faster the development of his moral logic as the basis for thinking, behaving and behaving according to morals prevailing in society (Colby \& Kohlberg, 1987).

Junior high school students entering the stage of adolescent development ideally always do goodness to others. For that, the school must work with learners in understanding the rules, and awareness of the effect of one's behaviour on others. One of them is parents. Hidayatullah (2010) explains about strategies in character education can be done through exemplary, disciplinary planting, habituation, creating a conducive atmosphere, integrity and internalization. In creating a conductive atmosphere, there is cooperation with parents.

In fact, based on the results obtained from the research, there are still many parents who are not actively involved in carrying out the procedure of using character book for students. Parents participate in socialization activities on the filling of character assessment books, and are willing to take the assessment book. However, some parents have not used this assessment book because they do not have spare time, heavy work activities, and assume that the implementation of the valuation book is complicated and less effective when it is given to adolescents. However, there are still some parents who consider character appraisal books to be effective enough to help parents control their child's behaviour at home. The parent's response about the use of character assessment books obtained based on research results are:

a. There are parents who claim that the character's character book is effective because it helps parents to control their children. In addition, parents also include their children to be involved in filling the book so that communication occurs between children and parents.

b. There are parents who argue that character appraisal books are ineffective because parents assume the child has behaved well due to sincerity to worship Allah Almighty, not because of punishment or gifts alone. Parents 
assume that character valuation books are no longer suitable for children who have entered adolescence, because adolescents behave due to rational reasons, no longer due to punishment / gifts alone. The character assessment book is considered to be more appropriate for children in primary school.

c. There are parents who argue that character assessment books are not very effective because parents who want their children to be positive by teachers in schools tend to show good behaviour to their children, so they do not provide information or data about actual teenage behaviour while at home. The information given by parents is hope, not fact.

d) Some parents have not used this assessment book because they do not have spare time, heavy work activities, and assume that the implementation of the valuation book is complicated and less effective when it is given to adolescents.

Scaffer (Saptono 2010) emphasizes the importance of parent roles involved in character building. This is because the family is the main character educator so it has the most important influence. The task of the school is to reinforce the values of the positive character taught at home. Schools as much as possible to provide parenting guidance related to character education programs in school. Involve parents in planning character education programs in school and give family homework to do in order to increase the agreed character.

Sulhan (2010) insists to be a character-based school with not enough vision, mission and goals. More concretely there is a foundation: commitment, motivation and togetherness. Thus, it can be said that the effectiveness of the character assessment book has not been effective enough to shape the expected student character. This is because parents are still less actively involved in the process of implementation of the character formation of children at home. This is in line with the opinion of Hidayatullah (2010) which states that one of the factors causing the low character education is the condition of the environment that is less support the development of good character.

\section{CONCLUSION}

a. Character that has been progressing in the student character related to the behaviour of conformist and activity of worship. Furthermore, the characters that still need to be strengthened in order to develop well include student-related behaviours (discipline, self-confidence, courage, and selfreliance) and behaviour related to others (good manners, communicating and behaving well).

b. Character assessment books are still less effective in improving students' positive characters. Some factors that affect the effectiveness of the character assessment book:

1) Lack of parental involvement in the process of using character appraisal books due to lack of spare time, dense work activities, and filling in character appraisal books is considered to be complicated.

2) Parents consider the child has done good behaviour due to sincerity to worship Allah Almighty, not because of punishment or gifts alone.

3) Parents assume that character valuation books are no longer suitable for children who have entered adolescence, because adolescents behave due to rational reasons, no longer due to punishment / gifts alone. The character assessment book is considered more appropriate for children in primary school.

\section{BIBLIOGRAPHY}

Ajikusumi, Clara (2010). Pendidikan karakter. Paper The main speaker. Proceedings of the National Conference of the Association of Educational Psychology Indonesi in UniversitasNegeri Malang. ISBN 978-602-97702$0-9$.

Andersen, Lorin. W. (1981). Assessing affective characteristic in the schools. Boston: Allyn and Bacon

Colby, A., Kohlberg, L., Gibbs, J., Lieberman, M., Fischer, K., Saltzstein, H.D. (1983). A Longitudinal Study of Moral Judgment. Monographs of the society for Research in Child Development. Vol. 48, No. 1/2, Hal. 1-124.

Colby, A., Kohlberg, L., Speicher, B., Hewer, A., Candee, D., Gibbs, J., \& Power, C. (1987). The Measurement of Moral Judgment Volume 1 : Theoretical Foundation and Research Validation. Retrieved from http://books.google.com

Colby, A., Kohlberg, L., Speicher, B., Hewer, A., Candee, D., Gibbs, J., \& Power, C.(1987). The Measurement of Moral Judgment Volume 2 : Standard Issue Scoring Manual. Retrieved from http://books.google.com

Danim Sudarwan. (2000). Metode Penelitian untuk ilmu-ilmu Perilaku. Jakarta: P Bumi Aksara

Emzir. 2013 (cetakanke 3). Metode Penelitian Kualitatif Analisa Data. Jakarta: Rajawali Pers.

Herman Kertajaya. (2010). Grow With Character. Jakarta: Gramedia

Hidfayatullah. Furqon. (2010). Pendidikan Karakter Membangun Peradaban Bangsa Surakarta: Yuma Pustaka

Koesuma, D. (2010). Mengembangkan Kultur Akademis Bagi Pembentukan Karakter Bangsa. Paper The main speaker. Proceedings of the National Conference of the Association.

Megawangi, R. (1999). Membiarkan Berbeda? Sudut Pandang Barutentang Relasi Gender. Pustaka Mizan, Bandung.

Munir. Abdullah. (2010). Pendidikan Karakter, membangun karakter Anak sejak dari Rumah. Yogyakarta: Pedagogia.

Ni'matuzahroh dan Prasetyaningrum S. (2014). Observasi dalam Psikologi. Malang: UMM Press 
Saptono. (2010). Dimensi-dimensi Pendidikan karakter. Wawasan, StrategidanLangkahPraktis. Jakarta: Erlangga.

Semiawan CR (2010). Peran Pendidikan Dalam Pembangunan KarakterBangsa. ProsidingKonfrensi Nasional AsosiasiPsikologi Pendidikan Indonesia di UniversitasNegeri Malang,

Sulhan.Najib. (2010). Pendidikan berbasisKarakter. Surabaya: PT JePe Press Media Utama 